\title{
Bad Faith? The Weak and Feeble Will of Antonio Coello's Elizabeth I
}

\section{Roy Norton}

\section{Christ Church, University of Oxford}

\begin{abstract}
A majority of the critics who have written about Coello's El conde de Sex have expressed surprise at the play's depiction of Elizabeth I, holding it to be a sympathetic portrayal that eschews the prejudices concerning the English queen held by seventeenth-century Spaniards. Mackenzie reads the character as praiseworthy even. This essay builds upon María Cristina Quintero's reading of the play and supports her contention that, contrary to this majority view, El conde does partake of many of these prejudices and presents a character, Isabela, who is far more ambivalent than has generally been recognized. Whereas Quintero focuses on the physical presentation of the queen, this essay considers her interior life. A close analysis of Isabela's thought processes demonstrates that Coello- - known for his subtle characterization—-presents his Isabela as an akrates, morally incontinent. Far from being a praiseworthy figure, this places the queen in the company of Phaedra, Macbeth, and Medea. Drawing on Lope de Vega's El castigo sin venganza and Calderón's La cisma de Inglaterra, this essay subsequently considers whether Isabela's akrasia should be attributed to the period's misogyny or to the Spanish view of the English queen's reformed religion. It concludes with an analysis of further evidence from El conde that points to the latter as the more likely reading. Quintero notes how in her Tilbury speech Elizabeth urged her nation to recognize in her the heart and stomach of her father, Henry VIII. Perhaps influenced by Calderón, Coello shows how, more worryingly, she inherited her father's weakness of will.
\end{abstract}


About thirty years after the death of Elizabeth I in 1603, Antonio Coello composed El conde de Sex, a play that has as its co-protagonist England's last Tudor monarch. The literature of early modern Spain contains many references to this woman who was, with some justification, seen as the nemesis of Spain's providentialist imperial project. Allusions to Elizabeth as the English Jezebel are ubiquitous, and they express the dominant view that here was a cruel, capricious, and, of course, heretical queen. And, before 1603, the Jezebel comparison must too have implied the hope that Elizabeth's regime, like the Old Testament queen's, would be overthrown in a manner that satisfied the smouldering hatred of her enemies-Jezebel was thrown from a high window and her naked flesh torn from her bones by a pack of dogs (2 Kings 9. 30-37), a degrading end that speaks loud and clear of God's vengeance for her persecution of the prophets of Yahweh and her perversion of the religion of Israel.

Lope de Vega's Corona trágica of 1627 includes multiple examples of the invective typical of the presentation of Elizabeth in early modern Spanish literature. In this epic poem concerning the pitiable life and martyrdom of Mary Stuart, Lope pours out against the regicide queen a deluge of insults. Elizabeth is "sangrienta Jezabel"; she is the Beast, the Fury Alecto, the "incestuoso parto de la Harpía," a "Lamia cruel” (I, 129; II, 32; II, 925; I, 133; and I, 137). And in La Dragontea of 1598 Lope has La Religión Cristiana compare Elizabeth Tudor to Medea (1. 167). To this standard image the writers of early modern Spain sometimes added details that explicitly specify Elizabeth's gender as a root cause of England's political misrule and her uncontrolled sexual appetites as a defining feature of her character. So, in his 1588 canción "De la armada que fue a Inglaterra," Góngora declares that England, that " $y a$ isla católica" is now condemned to eternal infamy because its current ruler has "la mano ocupada / del huso en vez del cetro y de la espada," and because, in Góngora's 
Spanish eyes, this spinning queen is, stingingly, a "[reina] libidinosa y fiera," "mujer de muchos, y de muchos nuera" (35, 46-47, 48, emphasis added). ${ }^{1}$

In light of the monochromatic, hostile depictions of Elizabeth that are quite predictably standard in early modern Spain, it is understandable that critical responses to $E l$ conde de Sex (circa 1633) have included—in several cases foregrounded—expressions of bewildered surprise that Antonio Coello's dramatic presentation of the queen should be such a sympathetic one. Applauding Coello's audacity in choosing to offer a generous depiction of “aquella reina tan odiada," Emilio Cotarelo y Mori, for instance, identifies the characterization of Elizabeth as the play's most surprising feature. For Cotarelo, Coello's Isabela is "dulce, sensible, honesta, digna, altiva, pero no cruel" (583). Raymond MacCurdy's critical response is very much in line with this. He writes that the queen, "much to the bewilderment of Spanish critics, is portrayed so sympathetically that she could well be recognizable to Englishmen as the good Queen Bess" (221). And Ann Mackenzie, like Cotarelo impressed that Coello apparently chose to rise above prejudiced commonplaces concerning Elizabeth, claims that the playwright "retrata una reina y mujer que es digna no sólo de nuestro elogio sino también de nuestra compasión” (“Antonio Coello” 44).

The potential for audience sympathy, for compassion, should certainly not be dismissed. Coello does not paint the queen as the savage monster of Lope's epic poems, but this difference is surely explainable in part by generic conventions. The typical comedia nиеva, for all its artificiality, does, generally, attempt to depict characters on stage in a manner intended to enable spectators to construct in their minds the impression of being faced with men and women who resemble living human beings. A character's appearance, actions, and —once the poetic language is distilled—words were crafted to elicit from seventeenth-century Spanish audiences a tacit concession that, "though this person does not exist, he is the kind of person that might exist" (to adapt one tenet of Aristotle's famous 
defense of poetry). In short, the dramatists of early modern Spain typically undertake to construct in the comedia not allegories but rather figures bestowed with a measure of psychological verisimilitude, judged by the standards of the day. All but the least of the period's dramatists appreciated the value of the grey in their character-painting palette as a promotor of suspension of disbelief. Coello's Isabela struggles with unenviable dilemmas that visibly cause her great distress. She is at times shown to be capable of tenderness and of selfless sentiments. Characteristics such as these will tend to inspire pity, of course, and often rightly so. To suggest that Coello's Elizabeth is praiseworthy, however, or that, in drawing her character, the playwright chooses to rise above the widespread, enduring prejudices of his contemporaries is to go too far. My purpose in this essay is to dispute this contention based on a distinctive feature of the queen's thought processes, as laid bare in dialogues and especially monologues that constitute dramatic climaxes in El conde. Isabela's habits of mind, her methods of practical reasoning, as inscribed into Coello's play text, are, precisely, those least befitting a prince, according to the period's kingship treatises.

Mine is not a lone voice is reading Coello's Queen Isabela as a figure more ambivalent than the critical consensus appears to suggest. In what is certainly one of the most stimulating and original pieces written on El conde, María Cristina Quintero questions the prevailing reading of this Elizabeth figure. She seeks, as shall I too in this essay, to rein in the unalloyed surprise and enthusiasm of the play's twentieth-century critics. She does so by showing that, quite contrary to the views of most critics, Coello's play does in fact, in Quintero's words, “[partake] of many of the prejudices toward the English queen and toward the rule of women in general that were characteristic of seventeenth-century Spain" ("English Queens"151).

Cotarelo y Mori supposes that Coello’s approach to characterizing Queen Elizabeth must have resulted from his awareness that the play would be watched by King Philip IV 
(and indeed it was staged at the palace in Madrid in 1633). ${ }^{2}$ Cotarelo argues that Coello had to present the queen, not as she was, but as monarchs were meant to be, splendour, prestige and majesty all intact (583). But, setting to one side its implications for Cotarelo's understanding of a whole host of comedias in which unworthy monarchs appear, this hypothesis surely flies in the face of - to name but one-the opening scene of El conde in which, pretty extraordinarily, Isabela enters on stage half-naked, dressed "en enaguas y cotilla, a medio vestir y con mascarilla" (24 [stage direction]), having spent a while washing herself in a tributary of the Thames beneath the voyeuristic gazes of at least three men (Essex and the two would-be assassins). ${ }^{3}$ By the standards of the day, that hardly speaks of regal decorum. Quintero focuses on this shocking physical depiction of Isabela and notes that, in $E l$ conde, "the queen who was famous for controlled self-display is seen making a sensual spectacle of herself"; she is "presented as an erotized object inadvertently performing a striptease for [Essex's] scopophilic delectation" ("English Queens” 152, 155). And so it is. Quintero makes this case persuasively, so I shall not dwell here on the extraordinary physical depiction of Isabela in Coello's play. Instead I shall consider the presentation of the queen's interior life, her psychological make-up. For in her set-piece speeches, Isabela makes a spectacle of herself, not physically, but intellectually: her habits in practical reasoning bear the hallmarks of akrasia, the weakness of will that, according to Aristotle and Aquinas, constitutes (quoting the former) one of the "moral states to be avoided," something "bad and blameworthy" (118-19). If Coello does indeed intend to depict Isabela as an akrates, as morally incontinent, as weak willed, then, rather than painting her as "digna de nuestro elogio," he is placing her among highly unflattering company: literary precedents of the akrates include Medea, Phaedra, and Macbeth. Of course, it is possible to feel some pity, some compassion, for each of these characters - the plays in which they feature would not 
have stood the test of time were it otherwise—-but I think it would be provocative, possibly even a little perverse, to read any of them as praiseworthy.

Akrasia is traditionally defined as "free, intentional action contrary to the agent's (decisive) better judgment" (Mele 7). For Aristotle "the incontinent man, knowing that what he does is bad, does it as a result of passion" (119). The most influential ethical discussions of the phenomenon come in book 7, chapter 3 of Aristotle's Nicomachean Ethics, and in Aquinas, especially his commentary on the Ethics, the Sententia libri Ethicorum. The best known literary source is the Medea story; she is the paradigm of the akrates. Juan Pérez de Moya's influential mythography, the Philosofía secreta, alludes to her moral incontinence, her free choice to do evil: "se dice de Medea [que] como conocedora del bien, despedazó a sus hijos y a su hermano, y dejó su tierra y su padre por seguir a Iasón” (562; book 4, ch. 53, emphasis added). At the start of book 7 of Ovid's Metamorphoses, as she resolves to betray her father and her nation for the benefit of Jason, a young man she has just met, Medea acknowledges plainly that reason is unequivocally counseling against the course of action she has in mind. The morally right course of action is quite evident to her, and yet she chooses to do wrong. Permitting her passions to override her reason, she says " $[0]$ ne way desire, another reason calls; / The better course I see and do approve_- / The worse I follow" (144). So akrasia is something more than the overwhelming of reason by passion that is such a common experience of characters in Calderonian drama. ${ }^{4}$ In the case of the akrates, the mind does reason and deliberate; it retains clear sight of what constitutes the rational, moral choice, yet it chooses wilfully to ignore the counsels of reason. The akratic mind will often achieve this morally perverse choice through a form of self-deception, as shall be demonstrated by the following account of Aristotle's example of the syllogism of the incontinent, which, for many modern scholars, lies at the heart of Aquinas's presentation of akratic reasoning (Pickavé 191). 
The mind of a continent agent might think in accordance with the following syllogism, then. Its major premise (relating to universal propositions) is that the consumption of three or more sweets per week is bad for one. As its minor premise (relating to particular propositions), it identifies that the sweet in front of it would, if consumed, be the third sweet of the week. And so, if these two premises are adequately related, the continent mind will conclude that the sweet should not be eaten and will counsel the will to act accordingly. The mark of the continent mind is that the will follows the reason's counsel. Now the akratic mind can tend not to approach practical reasoning in such a straightforward way.

Prompted by some desire aroused by the perception of an external object—in our case the sweet - the akratic mind will replace the bothersome, prohibitive major premise with an alternative, permissive one. Or it will quibble with the premises, typically the minor premise. It might, for instance, decide that the objectively full-size sweet before it seems, in fact, to be slightly smaller than the Platonic form of a sweet, calling it a mini-sweet, whose consumption would not, therefore, constitute that of a full third sweet. The conclusion would follow that the sweet might safely be eaten, then. These self-deceiving notions distract the mind from the original, correct syllogism and allow the akrates to decide that the desired course of action, the course that will satisfy the passions, can be justified. But, and this is important, the akratic agent retains within his mind the original syllogism, including its minor premise; this has simply been conveniently swept to one side, just to the fringes of mental sight. Desire has been allowed to interfere with practical reason. The akrates has wilfully blocked his true beliefs, the knowledge that would lead to morally correct inferences.

It can seem in some cases as if the akrates is not responsible for his actions, because he will consider the power of his passion to be irresistible. As Pickavé notes, "[b]ecause desire prompts us to abandon better judgment, it looks as if we aren't really responsible for what we are doing when we act incontinently" (193). Ovid's Medea, for instance, states that 
she believes that she has been bewitched. But for Aquinas this is self-deception: the incontinent agent's behaviour is voluntary, he chooses to stand down his reason, knowing he is about to do evil, and so, being freely done (for Aquinas insists that humans can resist their passions) it involves moral responsibility; it constitutes a kind of moral vice, a censurable moral disposition.

Critics have long praised the skill in characterization exhibited in El conde de Sex by its twenty-two-year-old playwright. Mackenzie speaks of a "predilección igualmente calderoniana de Coello por profundizar en la psicología de sus personajes. Coello muestra mucha aptitud para la creación de protagonistas complejos y verosímiles" (“Antonio Coello" 42). Rogers observes the "lucidez analítica" of the queen's speeches and concludes that "claridad en los pensamientos" is characteristic of Coello's dramatic style ("Los monólogos" 183, 190). Likewise, in his "critical appraisal" of the play Schmiedel notes enthusiastically the "sharp character delineation ... developed to an extent almost unknown to the comedia." He considers one of El conde's major attributes to be "the psychological development of the characters" (71). I shall argue now that part of this psychological development involves the inscription in Queen Isabela's speeches of self-deception, of akratic reasoning.

El conde de Sex is a relatively sparse play in terms of its dramatic action. If we choose to place the queen at the center of our analysis, we can say that, boiled down, it involves her struggling with two difficult dilemmas. The first is whether or not to act on her desire for the Earl of Essex, a spirited, self-assured young man who, early on in the play, begins to lavish special, flirtatious attentions upon the queen, but who is betrothed to, and very much in love with, Blanca, one of the queen's ladies-in-waiting. The second dilemma requires the queen to decide which of Essex and Blanca is a traitor to her. At the end of the act 2, the queen wakes from a nightmare to find Essex and Blanca together holding a single pistol to her head; one of them evidently wishes to assassinate her, the other is trying to rescue her. It is in thinking her 
way through these terrible dilemmas that, it seems to me, Coello shows his Virgin Queen to be an akrates, morally incontinent, all too ready to permit reason to be swayed by her passion, especially when her desire has been stirred by the physical presence of the young earl.

Isabela's first soliloquy comes at the end of act 1 , immediately following a scene in which Essex, fresh from his defeat of the Spanish Armada, comes to claim his reward from the queen. She quickly recognizes the earl as the gallant who saved her from an earlier assassination attempt, staged at the very start of the play (when she was half naked). Isabela is evidently attracted to Essex, and she quizzes him about the scarf he is wearing and his feelings for the woman who favored him with it, knowing full well that she herself is that woman, though she was wearing a mask at the time. Isabela very clearly hopes that Essex will have recognized her and that he will cast caution to the wind by declaring himself to be in love with her. In the face of his coyness, she considers making the first move on her vassal, though she knows that this could be considered unseemly. She just about manages to resist, but she instructs Essex to come to her later. That sets the scene for her soliloquy. Her concupiscence having been stoked by Essex's bodily proximity, she entertains romantic thoughts of her young favorite, banishing thoughts of Alençon, the French king's brother, at the English court to arrange his marriage to her. Initially, in the queen's mind, there appears to be no obstacle to an amorous relationship with Essex:

El Conde: ¿quién es el Conde?

Es galán: yo lo confieso;

es discreto: no lo dudo;

es valiente: yo lo creo;

es gallardo: ya lo miro;

es noble: yo no lo niego . . . . (999-1004) 
So far so good, then: nothing prevents a queen from forging a formal romantic relationship with a man who is gallant, shrewd, brave, handsome and noble. Impediments suddenly begin to rear their disagreeable heads in the queen's mind, however, as the course of her thoughts is diverted by a pero:

pero éste también, él mismo,

es desigual: yo lo temo;

es infeliz: se lo estimo;

es pobre: yo lo padezco;

es criado: yo lo lloro;

es vasallo: ya lo siento;

es humilde ....(1005-11)

The syllogism that underlies Isabela's thought process so far, then, might go as follows. The major premise, unspoken in this case, but surely easily supplied by Coello's audiences, would be that "a virtuous queen should only legitimately consider taking a partner who meets all of criteria W, X, Y, and Z." (Think, for instance, of the seemingly insurmountable obstacles that Diana identifies preventing her marriage to her criado, Teodoro, in Lope's El perro del hortelano.) As for Isabela's minor premise, well, Essex meets criteria W and X, but not Y and $\mathrm{Z}$. The logical conclusion to these premises, then, if they are adequately related, is clearly that Essex is not an acceptable match for the queen and that no further steps should be taken to romanticize the relationship. That is not the conclusion that Isabela reaches. The ellipsis within line 1011 indicates that the queen decides not to see this syllogism through, not, at least, according to the premises that reason suggested to her. And the continuation of the quotation makes the nature of her next intellectual move clear. She makes the move of an akrates. Dismissing the correct minor premise to the fringes of her mind, she replaces it, 
wilfully, with a rival one that, she anticipates, will lead her to the desired conclusion regarding Essex's suitability:

es humilde ... Mas no es tal:

miento yo, mil veces miento ... (1011-12; 1st ellipsis in original)

She replaces a restrictive premise with a permissive one. In contradiction of the legitimate concerns she has previously uttered, she determines that Essex is not, in fact, beneath her. And her akrasia, Isabela's willful self-deception, does not end there. Sensing, perhaps, that she cannot persuade even herself that her revised minor premise is tenable, she-quite extraordinarily—expresses her wish to be made blind to the truth, if she might be permitted thereby to have it her own way:

y si esto es verdad, memoria,

hazte olvidadiza de ello;

no me lo acuerdes, por Dios,

pues déjame, que yo quiero

regalar con la mentira,

lisonjear con el riesgo,

paladear con el daño

y halagar con el veneno.

Cese agora la cordura;

suspéndase un poco el seso,

y deje la voluntad

un rato al entendimiento. (1013-24)

The queen calls expressly on her will, the faculty whose resolutions, for Aquinas, determine the sinfulness of an act, to decouple itself from her understanding, from reason. To repeat, 
then, this is not a case, common in the Calderonian comedia, of a character failing to direct his will in accordance with reason, genuinely distracted by the seemingly overwhelming strength of his passion. No, Isabela actively wills this, and her reason is still making itself heard. And then she sets herself up to adopt a position of imposture, of bad faith. Coello's Isabela prepares to indulge herself for acting with what she decides in advance to paint as blindness or else the pitiable self-delusion of a woman with an infatuation:

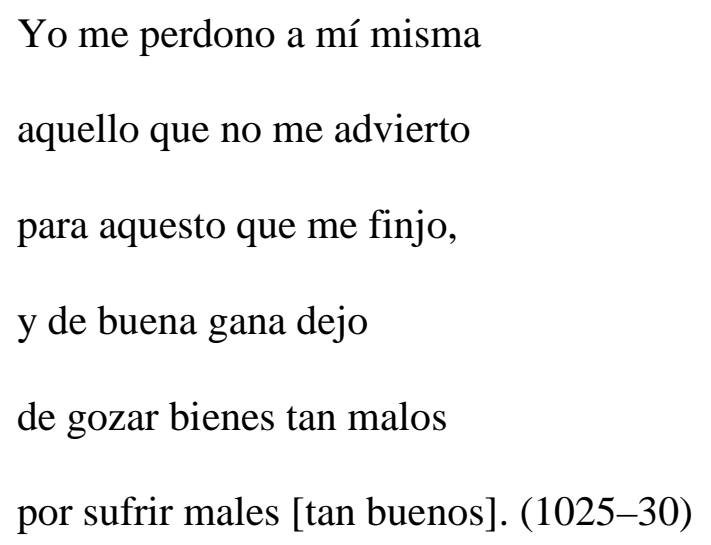

Clearly, she has in fact recognized (advertido) the grounds upon which she should resist her passions. Coello makes it quite clear that the queen can see through her own attempts to selfdeceive.

There are other scenes in El conde that show Isabela willing that her reason might be made impotent by passion, but, in fact, her reason remains strong, for instance, when she decides to deny Blanca her assistance in bringing forward that lady's marriage to Essex. (Blanca is betrothed to Essex, a fact that has led her to act on this palabra de esposo in the way that is conventional in the literature of early modern Spain.) Far from defending Blanca's honor, in lines that are strongly reminiscent of Don Gutierre's at the end of act 2 of El médico de su honra, Isabela warns her lady-in-waiting off her esposo. ${ }^{5}$ If some madwoman, the queen says, were to dare to lay her wanton eyes on Essex:

con las manos, con los dientes, con la vista, con las quejas, 
con la intención, con el ceño

o con las palabras mesmas,

¿no le quitara la vida,

la sangre no le bebiera

los ojos no le sacara,

y el corazón hecho piezas,

no le abrasara? (1793-1801)

Then, once alone on stage, Isabela calls again for circumstances to arise that would allow her to make her move on Essex despite the obvious moral and political impediments, in contradiction of the voice of her own reason, which is clearly counselling against such a course of action. Later, alone and determined that she does love the earl the queen begs:

Honor, duérmase; el recato

esta vez ahóguese sordo;

que confunde el sentimiento

la atención con el ahogo. (2357-60)

Again, then, she calls on passion ("el sentimiento") to drown out the voice of reason ("la atención"), which nevertheless remains perfectly audible to her. Elsewhere, the queen exclaims “i[o]h si no saber pudiera / aquello mismo que sé!” (2055-56). And elsewhere again “esto es verdad; y si no, / amor, no lo sepa yo, / o sépalo yo sin mí” (2098-100). The queen’s inclinations, and to some extent her actions, fly in the face of what she knows to be ethical and licit, such that, like Ovid's Medea, she might easily say "[o]ne way desire, another reason calls; / The better course I see and do approve_- / The worse I follow" (Ovid 144).

It should be conceded that modern spectators-by now great-grandsons and daughters of Freud and Jung-might well react towards the queen's attempts to self-deceive with 
comprehension and acceptance, especially considering that, ultimately in El conde de Sex, Isabela does not reach the moment when she must choose definitively whether or not to push her imprudent intent to its conclusions. She is not called upon to decide whether to "set asunder that which God has (all but) joined together" because events place before her the more pressing dilemma of the earl's possible treason. That said, though, an actor who participated in a 2016 rehearsed reading of an English translation of Coello's play did remark, unprompted, that $E l$ conde seemed to him to illustrate eloquently how easily a monarch such as Isabela can become a tyrant, when public policy and Christian morality come up against personal desire. ${ }^{6}$ Indeed, as is well known, discussions on tyranny found in political treatises of early modern Spain do list a failure to follow the light of reason as a prime characteristic of the tyrant. The point is made by Pedro de Rivadeneira in Tratado de un príncipe cristiano and by Pedro Martín Rizo in Norte de príncipes. ${ }^{7}$ And in his commentary on emblem 41 of the Idea de un príncipe político-cristiano, Diego Saavedra Fajardo underlines the importance of ensuring that the prince's will and his passions are always well governed by reason:

En lo que más ha menester el príncipe este cuidado es en la moderación de los afectos, gobernándolos con tal prudencia, que nada desee, espere, ame, o aborrezca con demasiado ardor y violencia, llevado de la voluntad, y no de la razón. (510)

Of course, in the case of the akrates, reason remains active, it is merely perverted by the will, which is even worse. Indeed, in the discussion of emblem 60, Saavedra identifies "la mayor enfermedad de la república" as none other than the prince's "incontinencia y lascivia" (710). Isabela expressly and repeatedly desires the overthrow of her own reason, and acts, or at least proposes to act, in defiance of it, preferring the call of her passion for Essex. She is not a brutish tyrant like the Segismundo of Acts 1 and 2 of La vida es sueño. On the contrary, her tendencies are those of a sophisticated egotist and her cold, calculating streak makes her, at 
times, an unsympathetic figure, albeit dressed in an attractive, majestic, often smiling exterior. Bernard McElroy's words on Shakespeare's akrates might well be applied to Coello's Isabela: “[t]he most terrible thing about [Macbeth's] tragedy is that he goes to it with his eyes wide open, his vision unclouded, his moral judgment still in perfect working order" (218). Therefore, because of Isabela's bad faith, her moral incontinence—a vice notoriously dangerous in a prince-it seems to me very unlikely that Coello was offering her to his spectators as a figure worthy of their esteem.

We may simply be dealing here with predictable early modern misogyny. As we saw, Lope and Góngora identify the gender of England's monarch as part of the perceived problem. Female rulers were the subject of excoriating tracts across early modern Europe, most famously of John Knox's 1558 First Blast of the Trumpet against the Monstruous Regiment of Women. It is not only physical weakness that was stereotypically associated with women, but intellectual and moral weakness too, along with a resultant predisposition to tyranny. Akratic thought processes also characterize one of the comedia's most famous female aristocrats, then, Casandra, in Lope's El castigo sin venganza, written in 1631, just a couple of years prior to El conde. ${ }^{8}$

Casandra's slide from continence to incontinence can be traced through the speeches she makes as she considers how to respond to her nascent desire for her stepson, Federico. Initially, she succeeds in exerting her willpower to resist her adulterous passion:

Las partes del conde son

grandes, pero mayor fuera

mi desatino si diera

puerta a tan loca pasión.

¡No más, necia confusión! (1572-76) 
She recognizes that were she to act on her desire ("si diera puerta a tan loca pasión"), such an act would constitute a "desatino." Her resilience weakens, though, when sexual attraction is coupled with the desire for vengeance that develops in the face of her husband's physical and emotional abandonment of her. Not long after she speaks the words quoted above, Casandra begins to consider acting on her passions more seriously and, like Medea, she sees the action she is contemplating for what it is, that is, evil:

$$
\begin{aligned}
& \text { En el ánimo que inclino } \\
& \text { al mal, por tantos disgustos } \\
& \text { del duque, loca imagino } \\
& \text { hallar venganzas y gustos } \\
& \text { en el mayor desatino. }
\end{aligned}
$$

$$
\begin{aligned}
& \text { Al galán conde y discreto, } \\
& \text { y su hijo, ya permito } \\
& \text { para mi venganza efeto ... (1821-28) }
\end{aligned}
$$

Note the active verbs used by the duchess here. She willfully inclines her soul towards the evil deed ("inclino") and knowingly gives in to her base desire for revenge ("permito"). Not long thereafter, Lope shows us her cognitive attempts at self-deception as she tries to divert her mind from the knowledge that her planned course of action is wrong. The syllogism her mind ponders here has as its major premise the notion that it is treasonous for a prince's consort to commit adultery. The minor premise, clearly, is that a sexual relationship with Federico would be adulterous (not to mention incestuous). The premises properly related, the conclusion of the continent mind should be that such a relationship would constitute an act of treason and the will should prevent its consummation. That Casandra's thoughts are developing along these lines, that she has reached this conclusion herself, tentatively, is demonstrated by her efforts to dismiss it: "hay dentro de mí quien dice / que si es amor no es 
traición" (1839-40). This novel defense to the charge of treason comes from within her mind. She is trying to sweep the inconvenient truth to the fringes of her purview and to smother it with this romantically charged notion. Casandra seeks to reinforce this rival analysis by looking for precedents of all-conquering love between fathers and daughters and between siblings. She finds them: "[a] sus padres han querido / sus hijas y sus hermanos / algunas" (1846-48). As Thacker observes, "[i]t is clear that, by the end of her speech, in spite of her bad conscience and her consciousness of its consequences, Casandra has determined on a course of action .... She will avenge herself on the duke and pursue her attractive young step-son" (200, emphasis added). Though the duchess back-peddles, aware of how "los que errar quisieron / siempre miran los que erraron, / no los que arrepintieron" (1986-88, emphasis added), she fails to re-focus her mind on the original, correct syllogism. With fatal consequences, she does the thing she desires, though she knows full well that it is wrong. Both women, then, Queen Isabela and Duchess Casandra, permit desire to interfere with their practical reasoning. The playwrights are careful to show how they willingly embrace incontinence.

Akrasia is not, though, the sole preserve of female characters in the comedia. Men too can be guilty of akratic thinking, for example, Enrique in Calderón's La cisma de Inglaterra (circa 1627). Rather than being considered a facet of Isabela's gender, then, her akrasia in El conde can be read as a symptom of her (from Coello's perspective) bad faith, the reformed religion that the historical Elizabeth inherited from her parents, especially her mother.

Calderón's Enrique is aware that his repudiation of Queen Catalina is illegitimate and that it offends against the Catholic truth he continues to hold dear despite his triggering of the schism, "la verdad que adoro es la que niego" (1724). He enacts moral evil with his eyes wide open. Through carefully worded soliloquies, Enrique is shown to retain the awareness that his actions are morally wrong even while he attempts to lead others into believing that 
his passions are blinding his reason. Before he stages a hypocritical show of desperate sorrow for the benefit of the dignitaries assembled in his throne room—-he weeps and laments that there is no alternative but to annul his marriage to Catalina—-the king admits to himself that his is a "falso argumento" (1731). For Enrique, all that matters is that his desires be satisfied in a manner that disguises his akrasia from his subjects. Vitally, this involves hiding his knowledge that his setting aside of Catalina is wrong. All that is required, he thinks, is that he create the appearance of believing his actions to be legitimate, of ignorance concerning their consequences:

Pero si un hombre el daño no alcanzara, aunque errara, parece que no errara; que en tan confusa guerra, sólo errará el que sabe cuándo yerra. $(1725-28)^{9}$

Returning to El conde de Sex, other details seem to suggest that singularidad, the original thinking for which the English (and other nations with a relatively flexible approach to faith) were censured by Catholic Europeans in the wake of their reformation, might be of broader interest to Coello in his depiction of the English court. Characters other than Isabela exhibit perverse, partial reasoning (not just akrasia) involving feats of intellectual gymnastics that, at one level, can be quite amusing. The serious point, though, is to show that not all reasoning is necessarily sound reasoning. For instance, the gracioso, Cosme, reasons through his decision to hold back from intervening in defense of his master, Essex, when the earl confronts the two men armed with pistols who have just tried to assassinate the queen. Asking himself, rhetorically, “¿Qué aguardo, / que no voy a socorrerle?”(10-11), Cosme explains:

Aguardo a que quiera el miedo dejarme entrar. Pues yo gasto 
linda flema. Si a eso espero,

bien socorreré a mi amo. (13-16)

The reasoning here is obviously spurious and intended to allow Cosme to determine that leaving Essex to face this danger alone is in fact the right course of action, when it is evidently a show of cowardice and fear, the passion conventionally characteristic of the figura del donaire. When the Duque de Alençon learns of a plot to assassinate the queen, in which he believes that Essex is implicated, in a mind-boggling display of intellectual ingenuity aimed at enabling him to play the part of noble, gallant hero, he devises this reasoning to justify his hubristic plan to keep Essex's plotting secret provided the plotting stops:

Sólo yo sabré este caso;

pero mal dije: yo mismo

no lo sabré; que, en saliendo

de aquesta cuadra que piso,

si agora he sabido aquesto,

después no lo habré sabido. (761-66)

Thus, Alençon claims illogically that he shall shortly never have known the fact he now knows! And finally, by way of example — there are many more-Essex himself evidently enjoys the romance of the paradox he devises to justify his dangerous decision to join the regicidal conspiracy in order to defeat it from the inside: "que soy más leal cuando / más traidor he parecido" (809-10). Ultimately, his loyalty to Isabela is revealed only after she has had him beheaded. For all the proud daring of his stratagem, Essex's gamble backfires.

It might be thought that, rather than suggesting something peculiar about the rationality of the English court, such paradoxes reflect Spanish literary fashions (going back 
at least to the cancionero poetry of the Middle Ages). That may be right. The density of the accumulation of instances of dubious, sometimes warped logic in El conde, however, leads me to prefer another conclusion. I suspect that Coello intended Isabela's akrasia to be echoed in the suspect ratiocinations with which her subjects and suitors attempt to justify their cowardly or hubristic actions.

Now it might appear that in arguing that Isabela is guilty of censurable intellectual habits I am substituting one reductive interpretation of Coello's Queen Elizabeth with another, countering the suggestion that she is piteous and estimable with a tendentious claim that she is immoral and rebarbative. In fact, the truth lies somewhere in between. My motive in focussing here on the queen's censurable characteristics is a sense that, particularly for a spectator or a reader unfamiliar with typical early modern Spanish thinking on kingship and tyranny, these characteristics can be easily overlooked. They can be overshadowed by the natural instinct to feel pity for a woman who loves a man already in love with another woman-all the more so when that woman is one who, as queen, cannot behave as others do, or when the woman is twice in the play very nearly the victim of fatal violence. The spectator or reader of early modern comedias should consider countering, or at least supplementing, instinctive emotional responses to characters and actions with sober, rational ones. Not every comedia hero who swoons and cries and rages against outrageous fortune is himself without blemish, sometimes serious blemish. Just as, anecdotally at least, the historical Elizabeth's facial blemishes lay hidden beneath a thick layer of white lead ceruse, the moral blemishes of Coello's queen can easily be obscured by her majesty, her coquetry, her righteous anger, and her desperate weeping. Her akrasia, I hope, has been at least plausibly demonstrated. Despite the stern words directed against the incontinent by the political theorists, however, weakness of will is probably neither especially uncommon nor particularly evil per se. The degree of wickedness that the seventeenth-century spectator would have perceived in a character's 
actions would have depended upon the precise nature of the actions the akratic mind permits itself to direct. Akrasia is not, though, the only unflattering facet of Isabela's character, a character that most critics have read as such an attractive one.

Comparisons with Medea, Phaedra, and Macbeth (as we have seen, the paradigmatic akrates of the western canon) might seem exaggerated, and indeed Isabela's offences fall far short of Medea's and Macbeth's in particular. And yet, in every case, there are possible parallels besides the moral incontinence I have discussed. Isabela does not kill her sovereign lord like Macbeth, no, but she has—a fact notorious in early modern Catholic Europedecreed (or at least failed to prevent) the murder of a monarch, Mary Queen of Scots. This historical episode provides the backdrop to Coello's play and the express motivation for the two assassination attempts enacted against Isabela. Indeed, the play's unusually neutral references to the defeat of the Spanish Armada might have been intended to provoke a piqued response from the corral audience. ${ }^{10}$ Its members could easily have recalled, in their internal justifications of the Enterprise of England, the event that sparked the Spanish attack, Mary's execution, thereby conditioning a hostile response to the woman who presided over it, that is, the very woman offered up for their "scopophilic delectation" at the start of the play. ${ }^{11}$ Coello's queen does not form an incestuous infatuation quite like Phaedra's for her youthful stepson, Hippolytus. But she does form an adulterous infatuation with the Earl of Essex, a man whom I take to be much younger than the queen (though the matter of the queen's age is left hazy in Coello's text). ${ }^{12}$ And Isabela does not murder her own children; she has none to murder. The murder of innocents is certainly not something alien to the prejudiced view that early modern Spain held of England's Queen Bess, however, or indeed to the action of $E l$ conde de Sex. If there is one thing that led to Elizabeth being reviled among Spaniards of the late sixteenth and seventeenth centuries it is her presiding over the execution, on charges of 
high treason, of the mainly Jesuit mission priests who sought in secret to reverse or to mitigate the effects on Catholics of the Anglican Schism from within England.

El conde de Sex ends with a final soliloquy from the queen in which she swears to wreak bloody vengeance against those she blames for her having ordered the execution of the Earl of Essex. He was innocent of treason, and guilty only of placing truth, love, and (a familiarly inflated sense of) honor above the kind of political expediency that, in Spanish eyes, motivated England's Reformation. I do wonder if the slaughter of this innocent, the Earl of Essex, by the woman Lope does refer to as England's cruel Medea, would have brought to the mind of the early modern Spanish spectator the slaughter of the mission priests, innocents, martyrs indeed to the Counter-Reformation cause. ${ }^{13}$ This link is left unspoken in El conde, but what the period's comedias only half-say, or leave unsaid, can be a most potent thing in the mind of a spectator just gently guided by the playwright and sensitive to cultural and historical intertexts.

Calderón presents his Henry VIII as a sophistical tyrant, who knowingly distorts universally accepted symbolism as a means of forging a new truth that enabled him to satisfy his personal desires (see Norton, "La verdad que adoro"). Antonio Coello, a disciple and collaborator of Calderón, may well have known La cisma de Inglaterra. In El conde Coello plays a variation on Calderón's theme by painting his Tudor monarch, Elizabeth, as an akrates, very much her father's daughter. Both playwrights must, I think, in choosing to characterize their protagonists as guilty of moral bad faith intend thereby to comment obliquely on the origins of what they would unquestionably have considered the bad religious faith of England, first introduced thanks to Henry's intellectual creativity, his singularidad, his willingness to call a spade a cat. While, unlike La cisma, El conde does not explicitly raise matters of religious controversy, the time and place of the action of Coello's play could not have been divorced from matters of religion by his intended spectators. The censor of the 
performance of El conde staged in 1661, nearly thirty years after the play was written and almost twice as long after Elizabeth's death, understood the sensitive, provocative nature of the material before him. His performance license includes an assurance that he took particular care in his assessment of the piece "por ser cosa de Inglaterra." 14

Rather than a woman "digna de elogio," Coello's Isabela is shown to think in a manner associated with tyrants. In her Tilbury speech, Elizabeth is reputed to have noted hers to be the weak and feeble body of a woman. Quintero has shown how Coello exposes the queen's body to humiliating eroticization at the start of El conde. Thinking of her father, Elizabeth proudly continued that speech by claiming to have the heart and stomach of a king, and of a king of England too. For Coello, Elizabeth's likeness to Henry VIII is nothing to boast about. On the contrary, the shared propensity to act in bad faith, to turn a blind eye to what both expressly concede to be righteous, is shown, in both La cisma and El conde, to have truly dreadful consequences. Never mind her weak and feeble body. It is Isabela's weak and feeble will that Coello shows to be so dangerous, all the more so because its workings can so easily pass unnoticed. 


\section{Works Cited}

Aristotle. Nicomachean Ethics. Edited and translated by Roger Crisp, Cambridge Texts in the History of Philosophy, revised ed., Cambridge UP, 2014.

Calderón de la Barca, Pedro. La cisma de Inglaterra. Edited by Francisco Ruiz Ramón, Castalia, 1981.

Coello, Antonio. El conde de Sex. Edited by Jesús Laiz, Clásicos RESAD / Fundamentos, 2006.

—. El conde de Sex: A Critical Edition and Study. Edited by Donald E. Schmiedel, Plaza Mayor, 1972.

Cotarelo y Mori, Emilio. “Dramáticos españoles del siglo XVII. Don Antonio Coello y Ochoa.” Boletín de la Real Academia Española, vol. 5, 1918, pp. 550-600.

Góngora, Luis de. "De la armada que fue a Inglaterra." Poesías completas, prologue by Niceto Alcalá-Zamora y Torres, vol. 2, Editorial Sopena Argentina, 1949, pp. 157-59. MacCurdy, Raymond R. "The Earl of Essex: Antonio Coello, El conde de Sex." The Tragic Fall: Don Álvaro de Luna and Other Favourites in Spanish Golden Age Drama, U of North Carolina, 1978, pp. 220-29.

Mackenzie, Ann L. “Antonio Coello como discípulo y colaborador de Calderón.” Calderón desde el 2000: Simposio Internacional Complutense, edited by José María Díez Borque, Ollero \& Ramos, 2001, pp. 37-59.

-. Review of Antonio Coello, El conde de Sex, edited by Donald E. Schmiedel. Bulletin of Hispanic Studies, vol. 53, no. 4, Oct. 1, 1976, pp. 348-50.

McElroy, Bernard. Shakespeare’s Mature Tragedies, Princeton UP, 1973.

Mele, Alfred R. Irrationality: An Essay on Akrasia, Self-Deception and Self-Control, Oxford UP, 1987. 
Norton, Roy. "Ironic Allusion and the Human Mind in Calderón's La cisma de Inglaterra." Modern Language Review, vol. 111, no. 4, 2016, pp. 1004-28.

—. “'La verdad que adoro es la que niego': Symbolism and Sophistry in Calderón's La cisma de Inglaterra." Bulletin of the Comediantes, vol. 68, no. 1, 2016, pp. 159-77.

Ovid. Metamorphoses. Edited by E. J. Kenney, translated by A. D. Melville, Oxford World's Classics, Oxford UP, 2008.

Pérez de Moya, Juan. Philosofía secreta de la gentilidad. Edited by Carlos Clavería, Cátedra, 1995.

Pickavé, Martin. “Aquinas on incontinence and psychological weakness.” Aquinas and the Nicomachean Ethics, edited by Tobias Hoffmann, Jörn Müller, and Matthias Perkams, Cambridge UP, 2013 [repr. 2015], pp. 184-202.

Quintero, María Cristina. "English Queens and the Body Politic." Gendering the Crown in the Spanish Baroque Comedia, Routledge, 2012, pp. 123-67.

—. “'The Body of a Weak and Feeble Woman': Courting Elizabeth in Antonio Coello's El conde de Sex." Material and Symbolic Circulation between Spain and England, 15541604, edited by Anne J. Cruz, Ashgate, 2008, pp. 71-87.

Rogers, Daniel. “El médico de su honra de Calderón y El conde de Sex de Coello.” Hacia Calderón: séptimo coloquio anglogermano, edited by Hans Flasche, Franz Steiner, 1985

—. "Los monólogos femeninos en El Conde de Sex de Antonio Coello." Estudios dedicados a James Leslie Brooks presentados por sus colegas, amigos y discípulos, edited by J. M. Ruiz Veintemilla, U of Durham / Puvill Libros, 1984, pp. 175-90.

Saavedra Fajardo, Diego. Empresas políticas. Edited by Sagrario López, Cátedra, 1999. Schmiedel, Donald E. Introduction. El conde de Sex: A Critical Edition and Study, by Antonio Coello, Plaza Mayor, 1972, pp. 10-76. 
Thacker, Jonathan. Commentary. Lope de Vega: El castigo sin venganza. Edited by Jonathan Thacker, Manchester UP, 2016, pp. 173-216.

Urzáiz Tortajada, Héctor. Catálogo de autores teatrales del siglo XVII, vol. 1, Fundación Universitaria Española, 2002.

Varey, J. E., and N. D. Shergold. Comedias en Madrid: 1603-1709. Repertorio y estudio bibliográfico. Fuentes para la Historia del Teatro en España, IX, Tamesis, 1989. Vega, Lope de. Corona trágica. Edited by Antonio Carreño-Rodríguez and A. Carreño, Cátedra, 2014.

---. El castigo sin venganza. Edited by Jonathan Thacker, Manchester UP, 2016.

---. La Dragontea. Edited by Antonio Sánchez Jiménez, Cátedra, 2007.

${ }^{1}$ Góngora's observation that Elizabeth's hands are busy with a spindle rather than a scepter and sword has obvious misogynistic implications. The spindle symbolizes an activity that the poet suggests is proper to women. It is implied that the accoutrements of political and military power are neglected or mishandled by the queen because her woman's nature is inevitably and powerfully inclined towards spinning (and, by extension, towards all those activities and characteristics stereotypically considered female by many in early modern Europe). The poem's fierce antipathy towards Elizabeth Tudor finds its expression in this facile commonplace, of a kind that pervades the period's discourse against the rule of women.

${ }^{2}$ El conde was premiered at the royal palace in Madrid on 10 November 1633 (Cotarelo 574). The play text was first published anonymously in Part 31 of the Diferentes (full title: Parte treinta y una de las mejores comedias que hasta hoy han salido, Barcelona, 1638). It has at times gone by the alternative titles La tragedia más lastimosa de amor and Dar la vida por su dama. The play is attributed to Coello in El mejor de los mejores libros (Alcalá, 1651), but, elsewhere, it is attributed, variously, to Calderón, Luis Coello, Matos Fragoso, and Pérez de 
Montalbán. Rumours also circulated that the "ingenio de esta corte," to whom El conde is attributed in certain eighteenth-century sueltas, was none other than Philip IV. That notion was fondly repeated by commentators in the nineteenth century, though based on no more than hearsay. The royal conjecture was roundly dismissed by Emilio Cotarelo y Mori, who pointed out that, had the play been written by the king, it is very unlikely that Francisco de Avellaneda, a man the king admired, would have censored it in 1661. In modern times critics appear to have settled upon authorship by Antonio Coello. Stylistic comparisons between $E l$ conde and other plays by Coello whose authorship is not disputed led Mesonero Romanos and, more recently, Donald Schmiedel, to confirm El conde as Coello's. For a fuller discussion of the authorship controversy, see Schmiedel's Introduction, 25-33. For further bibliographical details, see Varey and Shergold (85) and Urzáiz (263).

${ }^{3}$ All quotations (and corresponding verse numbers) from El conde are taken from Schmiedel's 1972 edition. Schmiedel's edition is based on the 1638 princeps with some material added from the second edition, of 1651 (more reliable in some regards than the earlier edition), and from the two manuscripts of El conde held at Madrid's Biblioteca Nacional, with shelfmarks MSS/16630 and MSS/16722. (See Schmiedel's "Introduction" for further details, esp. pp. 75-76.) Schmiedel's play text comprises 3092 lines of verse. The more recent modern edition edited by Jesús Laiz presents a heavily adapted text, the editor explaining that “[a] los 3092 vv. del texto de Coello le hemos quitado 592 vv., añadiéndole 195 vv. de nuestra propia cosecha para mejorar la comprensión, potenciar la trama o las subtramas y/o subrayar los temas y conflictos que nos parecían más relevantes" (25). This edition is useful, however, in particular for its account of the play's performance at Almagro in 2005 .

${ }^{4}$ At least "weak" incontinence is different, as opposed to "intemperate" incontinence. The latter involves the agent "instantly abandon[ing] previously held beliefs when tempted by 
desires and pleasures." The intemperate incontinent, then, does not deliberate upon the morality of his actions. The weak incontinent does (Pickavé 193, emphasis added).

${ }^{5}$ Calderón's El médico de su honra and Coello's El conde de Sex are close in terms of their probable dates of composition. The overlap between speeches made by Don Gutierre in the former play and the queen in the latter has led several critics to posit a common source or direct influence (with the direction of the influence remaining uncertain). See MacCurdy: and Rogers ("El médico").

${ }^{6}$ An English translation of this Coello play, with the title The Earl of Essex, is forthcoming in Aris \& Phillips.

${ }^{7}$ It should be remembered that the word tyrant is shouted at Isabela in the play's first line: “iMuere tirana!” As Quintero has noted, these words "frame the audience's and the reader's expectations and announce the serious treatment of potentially explosive topics such as sedition and tyrannicide." The three political theorists mentioned here are given as examples by Quintero ("The Body" 77, 83).

${ }^{8}$ I am grateful to Stephen Boyd, who suggested to me that I might usefully consider the case of Casandra.

${ }^{9}$ The dramatic development of Enrique's psychological character is treated in detail in Norton, "Ironic Allusion" and "'La verdad que adoro."”

${ }^{10}$ Essex refers to the defeat of the Armada when he is reunited with Blanca after the expedition. He recalls how their plan to inform the queen of their desire to marry was forcibly postponed when "Filipo / Segundo, español monarca, / contra Ingalaterra hizo / la armada mayor que nunca / con pesadumbre de pino / la espalda oprimió salobre / de aquese monstruo de vidrio; / y que a mí la Reina entonces / me envió con sus navíos / a procurar resistir / tan poderoso enemigo" (422-32). Later, Essex declares to the queen "[1]ibre está el reino; dejamos / de los españoles leños / limpio nuestro mar britano" (868-70). Despite what I 
perceive to be the relative neutrality of these references, the 1661 performance censor (see below) expunged the first quotation in its entirety and ordered the omission of the word “españoles” from the second (see Cotarelo 577-79), proving how very sensitive Spaniards continued to be about the defeat.

${ }^{11}$ Countering Schmiedel's sympathy for Blanca, Mackenzie describes Essex's betrothed as "[a] cold, calculating woman who twice attempts to assassinate her Queen, and lets her innocent lover suffer the ultimate penalty for her crimes, she is without doubt one of the most malevolent characters produced by Golden-Age drama" ("Review" 349). This seems to me an exaggerated response when one remembers that Blanca's father and brother were killed as a result of the queen's policies and that she herself has been forcibly deprived of her aristocratic status. One should also bear in mind, when assessing one's response to the character of Blanca, that the queen has screamed at her the order that she must never again so much as look upon her fiancé, that she must stop loving him. This must no doubt add to Blanca's fear that Essex might have been unfaithful to her and that the queen might be trying to destroy their relationship. I would suggest that Blanca is an ambivalent figure and therefore a compelling one, on both counts just like Isabela herself.

${ }^{12}$ The historical Essex first came to court in 1584 . He turned nineteen in that year. Elizabeth turned fifty-one.

${ }^{13}$ The link has been suggested by Quintero: “[t]he cruel punishment of the innocent Essex becomes in the play the metonymical dramatization of Elizabeth's persecution of Catholic martyrs, as perceived by Spaniards" (“The Body” 87).

${ }^{14}$ As Cotarelo records (577), a manuscript copy of El conde (Biblioteca Nacional de España, shelfmark MSS/16630) bears, on the penultimate page, the following censura: "Señor, he visto esta comedia del Conde de Sex con todo cuidado por ser cosa de Inglaterra, y, quitados unos versos que van anotados en la primera jornada, que tocan en la armada que el señor rey 
Felipe II aprestó contra aquel reino (noticia que no es bien se toque) y una redondilla en la segunda jornada de los validos, en todo lo demás el autor supo granjear su aprobación de vuestra señoría. Este es mi sentir. Madrid, a 11 de agosto de 1661. Don Francisco de Avellaneda." 